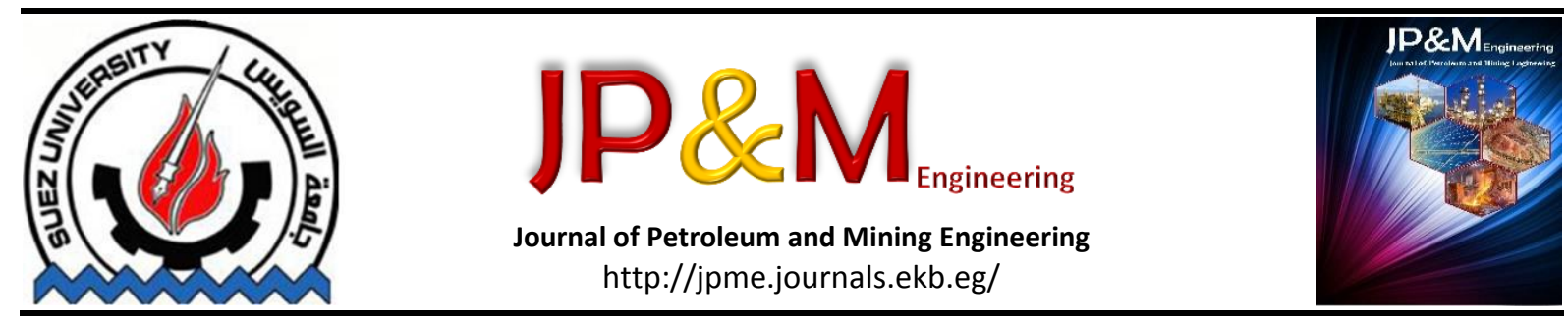

\title{
Selective Leaching for Uranium and Gold from their Bearing Sedimentary Lower Carbonaceous Sandstone Rocks, Southwestern Sinai, Egypt
}

\author{
Hisham K. Fouad, Randa M. Elrakaiby, Aziza I. Lotfy, Mohamed D. Hashim \\ Nationsl Research Institute- Egypt
}

\begin{abstract}
Uranium as a nuclear element with strategic importance and gold as one of the important economic precious metals made their selective leaching from the sedimentary lower carbonaceous sandstone rocks, Southwestern Sinai, Egypt with economic concentrations ( $5 \mathrm{ppm}$ gold and $160 \mathrm{ppm}$ uranium), an important issue for facilitating either their accurate determination or highest percentage recovery. A sequential leaching of uranium followed by gold was proposed in this work after studying individually their optimized leaching conditions. From the latter; a lixiviant mixture of sample to sodium carbonate ratio $1: 1$, sample to sodium bicarbonate ratio $1: 1$ together with sodium thiosulphate, as oxidant, $0.5 \mathrm{~g}$ was used for the selective leaching of uranium. On the other hand, a leaching reagent mixture of $5 \%$ $(w / v)$ from each of potassium cyanide, sodium thiosulphate and $10 \mathrm{ml}$ from $30 \%$ hydrogen peroxide was used for the selective leaching of gold where several factors were optimized; concentration of individual component in each lixiviant, agitation time, solid to liquid ratio, temperature and $\mathrm{pH}$. A percentage leaching of $97 \%$ and $96 \%$ for uranium and gold respectively were reached. Uranium was selectively separated using Amberlite IRA $402 \mathrm{Cl}$ resin ion exchange resin with $99.5 \%$ percentage recovery. The recovery of gold needs a large bulk weight from the sample due to its relatively low concentration.
\end{abstract}

\section{Keywords}

Leaching; Sandstone rock; Uranium

\section{Introduction}

The Uranium is recognized to be a critical commodity in the context of satisfying the global energy-demands for the twenty-first century and beyond. Low grade uranium bearing limestone rock, including mining waste, represents now a significant future uranium-resource, provided an economicallyviable method of extraction is developed. It is one of the basic elements of the peaceful nuclear power industry, where processing of uranium ores has the important role that would play in solving many energy problems, electrical utilities, and the need for a continuing high level of research activity in this field.

Leaching is a process by which a soluble substance is removed / extracted from gangue (undesirable matter) by the action of a percolating liquid, called lixiviant [1]. Uranium ores are treated by either acid or alkaline reagents with sulphuric acid or sodium carbonate - sodium bicarbonate systems used almost exclusively for commercial uranium recovery. As acidic leaching is a rapid process so the majority of uranium mills employ it but the fundamental advantage of the alkaline leaching is that most of the gangue is not attacked and the carbonate solutions can be regenerated [2]. In carbonate leaching, uranyl tricarbonate $\left[\mathrm{UO}_{2}\left(\mathrm{CO}_{3}\right)_{3}^{-4}\right]$ ion is formed which is stable and soluble although, the number of $\mathrm{CO}_{3}{ }^{-2}$ ions attached to the $\mathrm{UO}_{2}{ }^{+2}$ ion is a function of $\mathrm{pH}$ and ORP (oxidation-reduction potential) of the solution [3].

Acid leaching is preferred for low-lime ores due to faster leaching kinetics. Sulfuric acid is used almost exclusively in conventional uranium milling because of its low cost and compatibility with ion exchange recovery. Alkaline leaching is used when the ore contains high carbonate content. The advantages of the alkaline leaching process include higher selectivity and a lower corrosively than acid leaching. [2]

A variety of carbonate compounds can be used as complexing agents in the leaching/extraction of uranium from the ore body. The selection of a particular complexing agent depends upon its leaching efficiency, suitability for a particular ore type, easy availability as well as the economical load incurred in its use. However, in case of $\left(\mathrm{NH}_{4}\right)_{2} \mathrm{CO}_{3}$, precipitation of solid material started which could be 
seen in the drain pipes carrying the lixiviant discharge from the sample to the collection flasks. The precipitate when analyzed contained more than $50 \%$ $\mathrm{CaCO}_{3}$. This can be explained by observing the dissociation reactions of $\left(\mathrm{NH}_{4}\right)_{2} \mathrm{CO}_{3}$ as follows: $\left(\mathrm{NH}_{4}\right)_{2} \mathrm{CO}_{3} \rightarrow 2 \mathrm{NH}_{4}{ }^{+}+\mathrm{CO}_{3}{ }^{-2}$

$\mathrm{CO}_{3}{ }^{-2}+\mathrm{H}_{2} \mathrm{O} \leftrightarrow \mathrm{HCO}_{3}^{-}+\mathrm{OH}$

The carbonate is present in a large amount in the ore ( 4-8\%), but is not soluble in the lixiviants used. However, carbonate is formed in the dissociation reaction of the salt. In these circumstances, the internal $\mathrm{pH}$ of the sample loaded column may rise to such a value at which precipitation of calcium carbonate takes place in accordance with the reaction

$\mathrm{Ca}^{2+}+\mathrm{CO}_{3}{ }^{-2} \rightarrow \mathrm{CaCO}_{3}$ (ppt)

Thus, on these grounds, in spite of the high leaching efficiency of the compound $\left(\mathrm{NH}_{4}\right)_{2} \mathrm{CO}_{3}$ as complexing agent, it was not selected for the process.

The carbonate-bicarbonate lixiviants contain an anion that forms a soluble complex with uranium in its +6 charge state. The ratio of carbonate to bicarbonate can be raised by adding hydroxide and can be lowered by adding carbon dioxide. Leaching companies have tried carbonate-bicarbonate lixiviants having $\mathrm{pH}$ values from 6.5 to 10 . The current trend appears to use neutral or only moderately alkaline lixiviants.

Uranium in sedimentary phosphate rock was leached by alkaline solutions where, ammonium carbonate/bicarbonate leaching solution produces a stable uranyl carbonate [4].

Leaching of uranium-fertile granites represents a major source of uranium where this phenomenon is well documented at surface conditions, but remains poorly documented for granites at depth. Uranium was leached from the surface-derived oxidized hydrothermal fluid from uraninite in the Questembert peraluminous granite at temperatures greater than $70^{\circ} \mathrm{C}$ to $160^{\circ} \mathrm{C}$. [5]

Gold is one of the most important sources of currency entry in the economics of any state, it has a number of unique properties that makes it invaluable in industry, hence mining from its raw materials fit for effective gold extraction, and one of the ways of increasing effectiveness was direct hydrometallurgy processes. Selection of a leaching system for gold involves consideration of ore texture, mineralogy, chemical requirements and leaching techniques. Aqueous dissolution for gold requires an oxidant and a ligand to complex with gold in solution, with an effective $\mathrm{pH}$ adjustment. Leaching by cyanide solutions only has a set of substantial drawbacks; therefore, elaboration of new hydrometallurgical methods of extracting gold using nontoxic selective reagents was an important scientific and practical task. [6]

Gold extraction or recovery from low-grade oxide deposits may require a combination of comminution, mineral processing, hydrometallurgical, and pyrometallurgical processes. [7]
The Witwatersrand reefs bears gold, uranium, and pyrite in average concentrations of $\quad 0.001 \%, 0.02$ $\%$, and $1.7 \%$ respectively. Reverse leaching followed by a cleaning flotation step for the recovery of the pyrite, was an efficient process. [8]

Several lixiviant systems were proposed for gold dissolution as alkaline lixiviants; cyanide, ammoniacyanide, ammonia, sulphide, nitriles, neutral lixiviants; thiosulphate, halogens, sulphurous acid, and bacteria where $\mathrm{Au}(\mathrm{I})$ or $\mathrm{Au}(\mathrm{III})$ complexes were formed and others such as halides, malononitrile, acetonitrile and polysulfides. [9]

Cyanides, still one of the used reagents for recovering gold from its ores, where in refractory ores containing complex minerals, the gold dissolution is not a simple process and its rate becomes depressed after a certain time of cyanidation. Mineralogical identification of the ore and diagnostic leaching are alternative methods for establishing and designing a metallurgical flow sheet for refractory ores [10].

Acid leaching systems for gold may contain thiourea, thiocyanate, chlorine and aquaregia and the oxidants include chlorine, ferric chloride, hydrogen peroxide, and nitric acid which produce Au (III) anionic complexes, AuCl. For treating simple auriferous oxidesilicate-carbonate ores, and many other materials, cyanide remains the preferred lixiviant.

Combined leaching techniques were applied to high grade ores, which was processed by grinding, agitated cyanide leaching whereas low grades was heap or dump leached.

Uranium bearing gold ores was treated by cyanidation for gold extraction followed by sulphuric acid leaching of uranium from the cyanidation residue. Cyanide leaching can follow sulphuric acid leaching of uranium in a so called reverse acid leaching process. This can yield much higher gold recoveries by the virtue of the cleaning effect of sulphuric acid on free gold and dissolution of carbonates in the ore, which may contain a portion of gold values. [11,12]

The feasibility of leaching gold and uranium simultaneously from ores were investigated. Samples were leached in aerated solutions containing copper and cyanide made up in carbonate and bicarbonate medium at temperature range from $25^{\circ} \mathrm{C}$ to $90^{\circ} \mathrm{C}$. Results indicated that a temperature of about $50^{\circ} \mathrm{C}$ to $60^{\circ} \mathrm{C}$ would obtain uranium extraction between $85 \%$ and $90 \%$. [13]

The dissolution rate of uranium dioxide is a temperature dependent while gold is temperature independent in the range $60-80^{\circ} \mathrm{C}$. It was found that $85 \%$ of the uranium dioxide and $95 \%$ of the gold could be dissolved in a simultaneous leaching process. [14]

The extraction of uranium from Randfontein ore has been studied at a temperature of $110^{\circ} \mathrm{C}$ using sodium carbonate and sodium bicarbonate. The leach was followed by cyanidation of the ore to extract the gold. The results show that $90 \%$ of the uranium and $98 \%$ of the gold can be extracted by this technique but the 
consumption of sodium carbonate, at $65 \mathrm{~kg}_{\text {ton }}^{-1}$, is too high for the process to be economically competitive. The use of ammonium carbonate was also investigated and gave similar extraction values with apparently lower reagent consumption. [15]

In the present work, two separate leaching processes using different leaching parameters were studied on two portions of the sample for optimizing the individual leaching conditions for both uranium and gold. On the light of the obtained optimum leaching studied factors, a sequential leaching of uranium using a sodium carbonate / bicarbonate mixture together with sodium thiosulphate followed by gold from the remaining residue in a subsequent separate step using an alkaline medium by the cyanidation process (potassium cyanide, sodium thiosulphate and hydrogen peroxide as oxidizing agent) was performed. The percentage leaching efficiencies for uranium and gold were $99.5 \%$ and $98 \%$ respectively.

\section{Materials and Methods}

A technological sedimentary lower carbonaceous sandstone rock sample collected from southwestern Sinai, Egypt was the studied sample. It was crushed, ground to -200 mesh size and quartered for complete analysis for major oxides, trace elements, uranium and gold analysis. Scanning Electron Microscope (SEM) revealed the presence of micro size grains of gold and the radioactive mineral, uranothorite [16]. The total REE, U, Th, As, Cu were analyzed using ICPMS in Achme Laboratories, Canada, while gold was analyzed and monitored through the whole experiments using a studied developed gold determination procedure using AAS [17], and gold concentration in the rock sample was confirmed using the well known fire assay method in the Egyptian Geological Survey Laboratories and confirmed.

Atomic absorption spectrometer model Unicam 969 supplied with acetylene and nitrous oxide burner heads was used for analysis of gold after extraction with MIBK and stripping from the leach liquor.

The fire assay analysis of gold assured the presence of economic concentrations of 5 ppm gold and $160 \mathrm{ppm}$ uranium analyzed volumetrically by the known Davies and Gray [18]. The chemical analyses of major and trace concentrations in the studied sample were shown in Table (1).

Two representative portions of the studied sample were considered for individual optimization for leaching tests, where different leaching factors were studied namely; effect of solid to liquid S/L ratio, temperature, agitation time, concentrations of individual leaching reagent and $\mathrm{pH}$. On the light of the optimum obtained results a sequential leaching, on a third portion of the sample, for uranium followed by subsequent leaching for gold was performed.
Table (1):_Analysis of major, trace, uranium and gold concentrations in the studied sample

\begin{tabular}{|c|c|}
\hline Heading & Heading \\
\hline $\mathrm{SiO} 2$ & 71.0 \\
\hline $\mathrm{Al} 2 \mathrm{O} 3$ & 5.30 \\
\hline $\mathrm{Na} 2 \mathrm{O}$ & 0.60 \\
\hline $\mathrm{K} 2 \mathrm{O}$ & 0.27 \\
\hline $\mathrm{CaO}$ & 3.10 \\
\hline $\mathrm{MgO}$ & 0.92 \\
\hline $\mathrm{TiO} 2$ & 0.04 \\
\hline $\mathrm{P} 2 \mathrm{O5}$ & 0.86 \\
\hline $\mathrm{Fe} 2 \mathrm{O} 3$ & 8.48 \\
\hline $\mathrm{FeO}$ & 0.42 \\
\hline L.O.I & 6.80 \\
\hline Trace Elements & Concentration (ppm) \\
\hline $\mathrm{Au}$ & 5.0 \\
\hline $\mathrm{Ag}$ & 10.0 \\
\hline $\mathrm{U}$ & 160 \\
\hline Th & 8.60 \\
\hline$\sum$ REE & 513 \\
\hline $\mathrm{Cu}$ & 128 \\
\hline As & 125 \\
\hline
\end{tabular}

\section{Results}

\section{Leaching process of Uranium}

The uranium in rocks and ores is usually present as $\mathrm{UO}_{2}$ or $\mathrm{U}_{3} \mathrm{O}_{8}$ and requires oxidation to be converted to $\mathrm{UO}_{3}$ before its dissolution as $\mathrm{UO}_{2}\left(\mathrm{CO}_{3}\right)_{3}{ }^{4-}$ ion. Uranium was the leached using alkaline mixture of carbonatebicarbonate leach solution together with sodium thiosulphate which has the possibility for leaching the hexavalent uranium from carbonate rocks.

In presence of carbonate leaching:

$\mathrm{U}_{3} \mathrm{O}_{8}+1 / 2 \mathrm{O}_{2}+9 \mathrm{CO}_{3}{ }^{2-}+3 \mathrm{H}_{2} \mathrm{O} \rightarrow 3 \mathrm{UO}_{2}\left(\mathrm{CO}_{3}\right)_{3}^{4-}+6 \mathrm{OH}^{-}$

In presence of bicarbonate leaching:

$\mathrm{U}_{3} \mathrm{O}_{8}+\frac{1}{2} \mathrm{O}_{2}+3 \mathrm{CO}_{3}{ }^{2-}+6 \mathrm{HCO}_{3} \rightarrow 3 \mathrm{UO}_{2}\left(\mathrm{CO}_{3}\right)_{3}{ }^{4-}+3 \mathrm{H}_{2} \mathrm{O}$

For UO2 the equivalent reaction is:

$\mathrm{UO}_{2}+1 / 2 \mathrm{O}_{2}+\mathrm{CO}_{3}^{2-}+2 \mathrm{HCO}_{3}-\rightarrow \mathrm{UO}_{2}\left(\mathrm{CO}_{3}\right)_{3}{ }^{4-}+\mathrm{H}_{2} \mathrm{O}$

The presence of bicarbonate in the solution is essential to prevent the formation of excess hydroxyl ion, which would lead to the precipitation of sodium uranate. [19] On the contrary insufficient bicarbonate concentration would lead to slow down the reaction rapidly. Several factors were studied for the maximum and selective leaching of uranium namely; concentration of carbonate, concentration of bicarbonate, sodium thiosulphate concentration, $\mathrm{pH}$, temperature, agitation time and solid to liquid ratio (S/L).

\section{Effect of sample to sodium carbonate ratio}

The effect of sample to sodium carbonate ratio on the efficiency of uranium leaching was studied from 1:0.25 to $1: 2$ ratio, while the other conditions were kept constant; sample to $\mathrm{NaHCO}_{3}$ ratio $1: 1$, e to $\mathrm{Na}_{2} \mathrm{~S}_{2} \mathrm{O}_{3} 0.5 \mathrm{~g}, \mathrm{pH} 9.5,2$ hours agitation time at $50^{\circ} \mathrm{C}$. From the results illustrated in Figure (1), it can be concluded that the percentage leaching efficiency of 
uranium increases with the increase of sample to sodium carbonate ratio then becomes constant from a ratio $1: 1$, which was considered the optimum ratio.

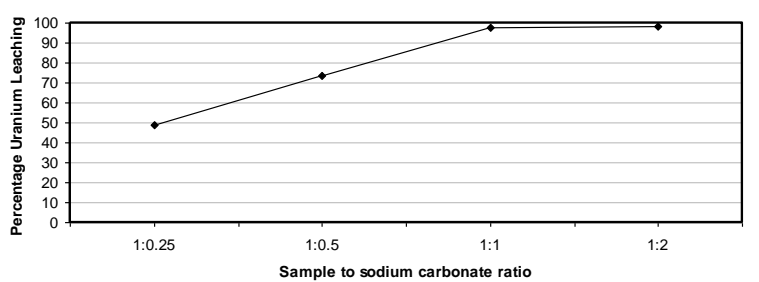

Figure (1): Effect of sample to sodium carbonate concentration on leaching uranium leaching

\section{Effect of sample to sodium bicarbonate ratio}

The effect of sample to sodium bicarbonate ratio on the efficiency of uranium leaching was studied between 1:0.25 - 1:2 ratio, while the other conditions were fixed; sample to $\mathrm{Na}_{2} \mathrm{CO}_{3}$ ratio $1: 1, \mathrm{Na}_{2} \mathrm{~S}_{2} \mathrm{O}_{3} 0.5 \mathrm{~g}$, $\mathrm{pH} 9.5,2$ hours agitation time at $50^{\circ} \mathrm{C}$. The results illustrated in Figure (2) concluded that the highest percentage leaching efficiency of uranium reached was at sample to sodium bicarbonate ratio 1:1.

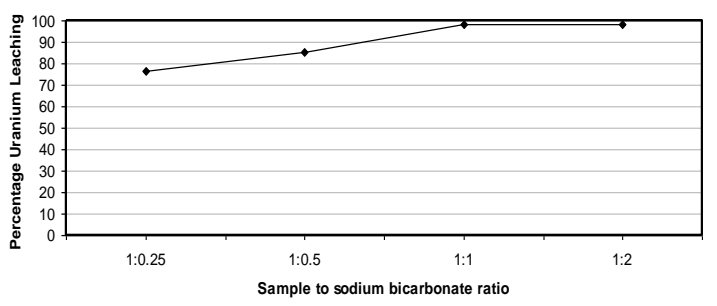

Figure (2): Effect of sample to sodium bicarbonate ratio on uranium leaching

\section{Effect of sodium thiosulphate}

The effect of sodium thiosulphate, as an oxidizing agent, on the maximum leaching efficiency of uranium was studied from $1 \mathrm{~g}$ till $2 \mathrm{~g}$ while the other factors were kept constant; sample to $\mathrm{Na2} 2 \mathrm{O} 3$ ratio 1:1, sample to $\mathrm{NaHCO} 3$ ratio 1:1, pH 9.5, 2 hours agitation time at $50 \circ \mathrm{C}$. The obtained data presented in Figure ( 3 ) clarifies that adding $0.5 \mathrm{~g}$ of sodium thiosulphate was optimum for maximum leaching offirionry of uraniım

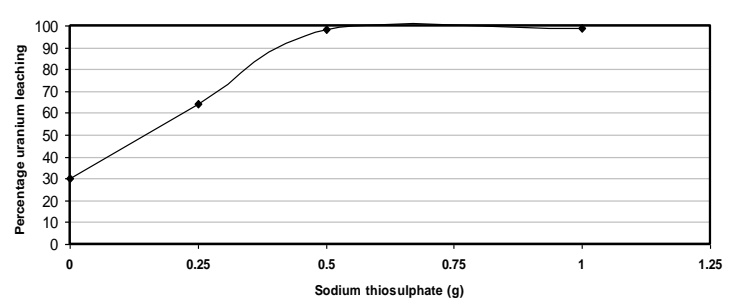

Figure (3): Effect of sodium thiosulphate on leaching uranium leaching

\section{Effect of pH}

The effect of different $\mathrm{pH}$ values of the leaching reagent for maximum leaching efficiency of uranium, was studied from 5-11 while the other optimum studied factors were kept constant; sample to
$\mathrm{Na} 2 \mathrm{CO} 3$ ratio $1: 1$, sample to $\mathrm{NaHCO} 3$ ratio $1: 1$, $\mathrm{Na} 2 \mathrm{~S} 2 \mathrm{O} 30.5 \mathrm{~g}, 2$ hours agitation time at $500 \mathrm{C}$. From the results obtained and illustrated in Figure (4), it was obviously clear that the percentage leaching efficiency increases with the increase in $\mathrm{pH}$ till a value of 9.5 after which a plateau was observed where the latter $\mathrm{pH}$ was effective in the leaching percentage of uranium as shown.

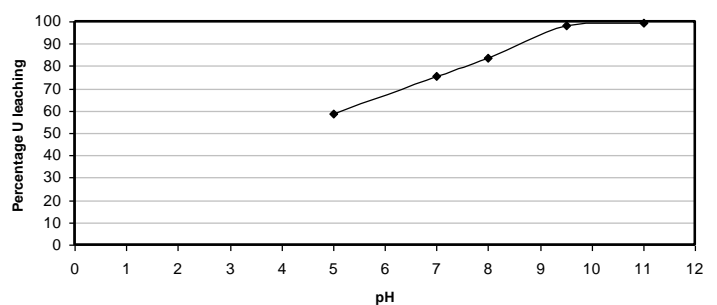

Figure (4): Effect of $\mathrm{pH}$ on leaching percentage of uranium leaching

\section{Effect of agitation time}

The effect of agitation time on percentage leaching efficiency of uranium was studied from 30 minutes till three hours, while the other studied conditions were fixed; sample to $\mathrm{Na} 2 \mathrm{CO} 3$ ratio $1: 1$, sample to $\mathrm{NaHCO} 3$ ratio $1: 1,0.5 \mathrm{~g} \mathrm{Na} 2 \mathrm{~S} 2 \mathrm{O} 3, \mathrm{pH} 9.5$ at $50 \circ \mathrm{C}$. The data shown in Figure (5) illustrated that the percentage leaching of uranium was increased with time from 30 minutes till 120 minutes (97\%), after which there was no increase observed; hence two hours was concluded as the optimum agitation time for maximum leaching percentage of uranium.

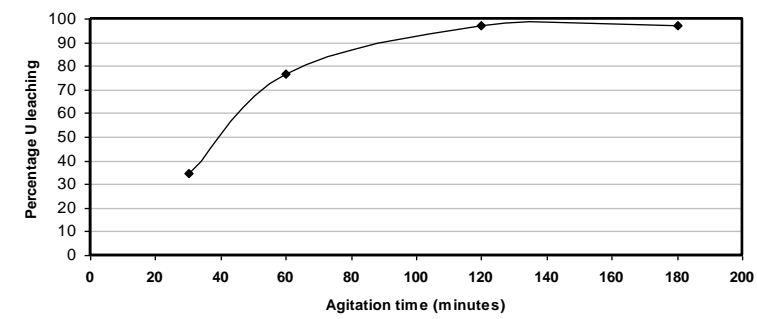

Figure (5): Effect of agitation time on percentage leaching of uranium.

\section{Effect of temperature}

The effect of different studied temperatures, ranging from $250 \mathrm{C}$ till $750 \mathrm{C}$, for maximum leaching of uranium, were studied while the other optimized studied factors were fixed; sample to $\mathrm{Na} 2 \mathrm{CO} 3$ ratio 1:1, sample to $\mathrm{NaHCO} 3$ ratio $1: 1,0.5 \mathrm{~g} \mathrm{Na} 2 \mathrm{~S} 2 \mathrm{O} 3, \mathrm{pH}$ 9.5 and two hours agitation time. From the data obtained and illustrated in Figure (6) it was obviously clear that the percentage leaching efficiency of uranium increases with the increase in temperature till $500 \mathrm{C}$ with $97 \%$ leaching efficiency for uranium after which a plateau was formed indicating that the latter temperature was the optimum for maximum uranium leaching. 


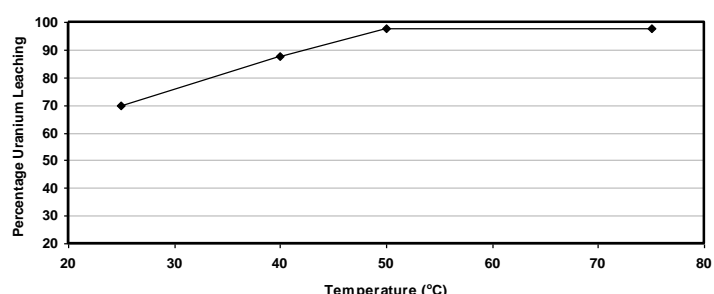

Figure (6): Effect of temperature on percentage leaching of uranium

After studying the optimum conditions for maximum leaching efficiency of uranium from the studied carbonaceous sandstone sample with a percentage leaching efficiency of $98 \%$, hence its recovery as nuclear strategic element using Amberlite IRA402 Cl [20] was of great importance for further processing, where a percentage recovery of $99.5 \%$ for uranium was reached.

\section{Leaching process for gold}

After the optimized studied parameters for maximum uranium leaching with percentage leaching efficiency $97 \%$ and its separation, leaching experiments on gold were carried out using a second $25 \mathrm{~g}$ of the sample with $5 \mathrm{ppm}$ gold concentration and a lixiviant mixture of potassium cyanide, sodium thiosulphate and hydrogen peroxide. Experimental leaching parameters studied for gold were $1-5 \%(w / v)$ for each of sodium thiosulphate and potassium cyanide ( $\mathrm{KCN}), 1-15 \% \mathrm{H}_{2} \mathrm{O}_{2}(30 \% \mathrm{v} / \mathrm{v})$ at $\mathrm{S} / \mathrm{L}$ ratio from $1: 3$ to $1: 6$ with leaching time ranging from 0.5 hour to 3 hours, $\mathrm{pH}$ from $8-12$ at a temperature from $25^{\circ} \mathrm{C}$ to $60^{\circ} \mathrm{C}$.

\section{Effect of potassium cyanide concentration}

The effect of potassium cyanide concentration was studied from $0-5 \%(\mathrm{w} / \mathrm{v})$ while the other leaching conditions were fixed; $5 \% \mathrm{Na2S} 2 \mathrm{O} 3,10 \mathrm{ml}$ from $30 \%$ $\mathrm{H} 2 \mathrm{O} 2$, two hours stirring time, $\mathrm{pH} 9.5,25 \mathrm{oC}$ and $\mathrm{S} / \mathrm{L}$ ratio $1: 10$. From Figure (7) it can be obviously illustrated that $5 \% \mathrm{KCN}$ was an efficient concentration with $95 \%$ percentage leaching efficiency where gold was leached in the form of soluble aurocyanide complex ion, $\mathrm{Au}(\mathrm{CN})-2$ and was presented by the following equation:

$2 \mathrm{Au}+4 \mathrm{CN}^{-}+1 / 2 \mathrm{O} 2+\mathrm{H} 2 \mathrm{O} \rightarrow 2 \mathrm{Au}(\mathrm{CN}) 2^{-}+2 \mathrm{OH}$

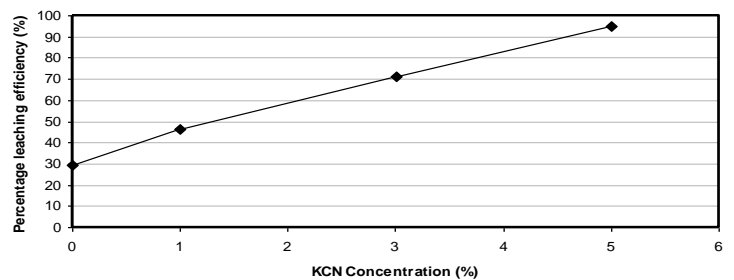

Figure (7): Effect of KCN concentration on gold leaching

\section{Effect of sodium thiosulphate concentration}

Several leaching experiments were performed to attain the optimum concentration of sodium thiosulphate (from 0 to $5 \% \mathrm{w} / \mathrm{v}$ ) for maximum leaching of gold while the other conditions were fixed; $5 \% \mathrm{KCN}, 10 \mathrm{ml}$ from 30\% H2O2, pH 9.5, 2 hours stirring time, $250 \mathrm{C}$ and $1: 10 \mathrm{~S} / \mathrm{L}$ ratio.

Figure (8) indicated that the highest percentage leaching efficiency for gold ( $96 \%$ ) was attained at $5 \%,(w / v) \mathrm{Na} 2 \mathrm{~S} 2 \mathrm{O} 3$

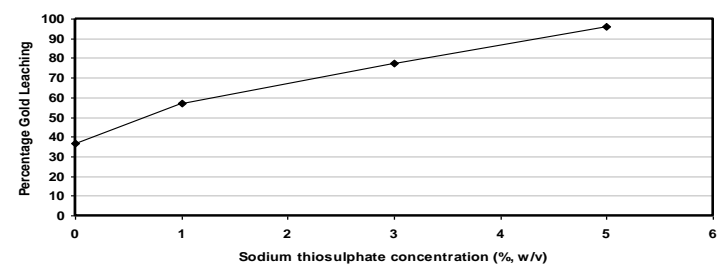

Figure (8): Effect of sodium thiosulphate concentration on gold leaching

\section{Effect of hydrogen peroxide concentration}

The percentage leaching efficiency of gold without and with different hydrogen peroxide concentrations (30\%) affecting gold leaching was studied while the other factors namely; $5 \% \mathrm{KCN}, 5 \% \mathrm{Na} 2 \mathrm{~S} 2 \mathrm{O} 3, \mathrm{pH} 9.5$, 2 hours stirring time, $25 \circ \mathrm{C}$ and $1: 10 \mathrm{~S} / \mathrm{L}$ ratio were kept fixed. Figure (9) illustrated that the optimum hydrogen peroxide volume from $30 \%$ hydrogen peroxide was $10 \mathrm{ml}$ giving a maximum percentage leaching efficiency value of $95.9 \%$ after which a plateau was formed.

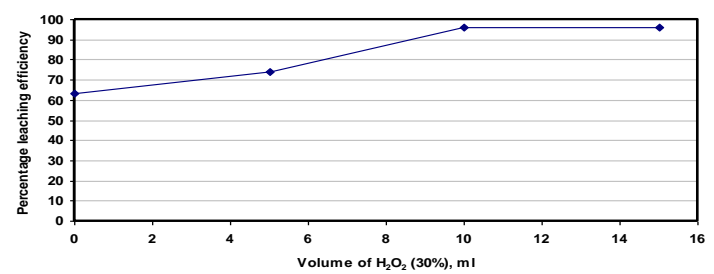

Figure (9): Effect of hydrogen peroxide concentration on gold leaching

\section{Effect of temperature}

The effect of temperature, in the range from $250 \mathrm{C}$ till $600 \mathrm{c}$, on the leaching efficiency of gold was studied, and the other leaching factors were constant; $5 \% \mathrm{KCN}, 5 \% \mathrm{Na}_{2} \mathrm{~S}_{2} \mathrm{O}_{3}, \mathrm{pH} 9.5,2$ hours stirring time, 10 $\mathrm{ml}$ from $30 \% \mathrm{H}_{2} \mathrm{O}_{2}$, and $1: 10 \mathrm{~S} / \mathrm{L}$ ratio. From the gathered data illustrated in Figure (10) it was obvious that the increase in temperature decreases the leaching efficiency of gold from $96 \%$, at room temperature $250 \mathrm{C}$, till it reaches $89.2 \%$ at $600 \mathrm{C}$. This may be attributed to the dissociation of hydrogen peroxide, at about $500 \mathrm{C}$ and reaches its maximum at $600 \mathrm{C}$, to water and oxygen, hence becomes inefficient as an oxidizing agent.

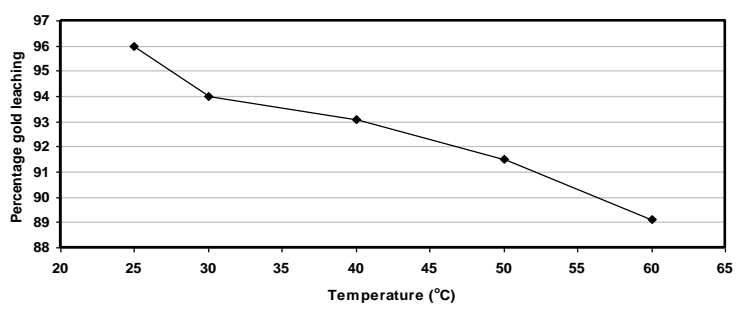

Figure (10): Effect of temperature on gold leaching 


\section{Effect of agitation time}

The effect of agitation time on leaching of gold was studied from half to 3 hours, where the other conditions were kept constant; $5 \% \mathrm{KCN}, 5 \%$ $\mathrm{Na} 2 \mathrm{~S} 2 \mathrm{O} 3, \mathrm{pH} 9.5,10 \mathrm{ml}$ from $30 \% \mathrm{H} 2 \mathrm{O} 2,250 \mathrm{C}$ and $1: 10 \mathrm{~S} / \mathrm{L}$ ratio. From the obtained data illustrated in Figure (11), it was obviously clear that the leaching efficiency of gold increases proportionally with time till two hours after which it gives a constant value, thus two hours was selected as the optimum agitation time.

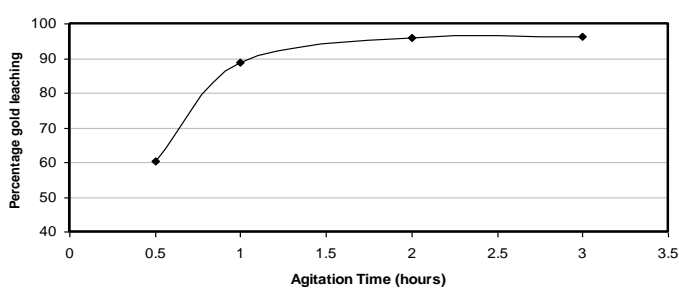

Figure (11): Effect of agitation time on gold leaching

\section{Effect of $\mathrm{pH}$}

The effect of $\mathrm{pH}$ of the leaching solution on gold leaching was studied from $\mathrm{pH}$ 8-12 with the other studied factors kept constant; $5 \% \mathrm{KCN}, 5 \% \mathrm{Na} 2 \mathrm{~S} 2 \mathrm{O} 3$, 2 hours stirring time, $250 \mathrm{C}, 10 \mathrm{ml}$ from $30 \% \mathrm{H} 2 \mathrm{O} 2$ and $1: 10 \mathrm{~S} / \mathrm{L}$ ratio, the results obtained were illustrated in Figure (12) which indicated that the leaching efficiency of gold increased with the increase of $\mathrm{pH}$ till it reached a maximum leaching efficiency of 95.9 $\%$ at $\mathrm{pH} 9.5$ after which no increase was observed

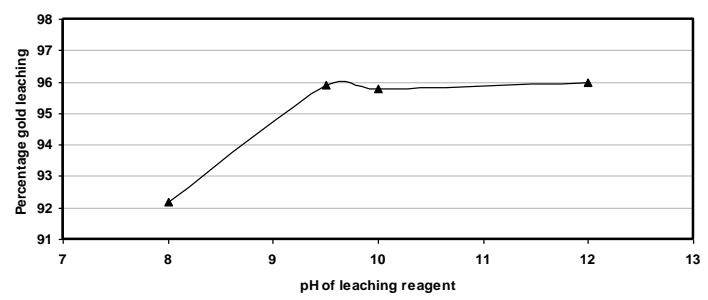

Figure (12): Effect of $\mathrm{pH}$ of leaching reagent on gold leaching

\section{Effect of solid to liquid ratio}

The effect of solid to liquid ratio on gold leaching was studied from 1:3 to $1: 10$, using the previously optimized factors; 5\% KCN, 5\% Na2S2O3, 2 hours stirring time, $250 \mathrm{C}, 10 \mathrm{ml}$ from $30 \% \mathrm{H} 2 \mathrm{O} 2$ and $\mathrm{pH} 9.5$. The obtained gold leaching results illustrated in Figure (13) indicated that as the $S / L$ ratio increases the percentage gold leaching efficiency increase till it reaches $96 \%$ at $S / L$ ratio of $1: 10$.

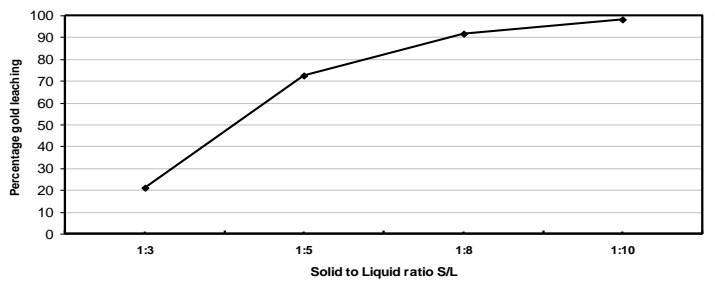

Figure (13): Effect of solid to liquid (S/L) on leaching of gold
From the above studied parameters for gold leaching from its bearing carbonaceous technological sample, it can be concluded that the optimum conditions for the highest leaching percentage for gold (96\%) were $1: 10 \mathrm{~S} / \mathrm{L}$ ratio, 2 hours agitation time, $25^{\circ} \mathrm{C}, 5 \%(\mathrm{w} / \mathrm{v})$ potassium thiocyanate, $5 \%(\mathrm{w} / \mathrm{v})$ sodium thiosulphate, and $10 \mathrm{ml}$ from $30 \% \mathrm{H}_{2} \mathrm{O}_{2}$ at $\mathrm{pH} 9.5$. After optimum leaching conditions were performed on the sample, we reached leach liquor with $4.9 \mathrm{ppm}$ $\mathrm{Au}$ concentration, $(98 \%$ leaching efficiency or recovery).

Table (2) summed up the optimum leaching conditions for both uranium and gold from the studied sample. From the obtained data, it was revealed that selective leaching of uranium followed by gold was most effective for maximum percentage leaching efficiency of both elements in two sequential leaching steps, with two separate leach liquors and percentage leaching efficiencies of $97 \%$ and $98 \%$ for uranium and gold respectively. Uranium was recovered using Amberlite-IRA $402 \mathrm{Cl}$ as it is one of the main important targets of our authority.

Table (2): Optimum parameters for maximum leaching efficiency for uranium and gold

\begin{tabular}{|c|c|c|c|}
\hline \multicolumn{2}{|c|}{$\begin{array}{l}\text { Studied Parameters for U } \\
\text { leaching }\end{array}$} & \multicolumn{2}{|c|}{$\begin{array}{c}\text { Studied Parameters for Au } \\
\text { leaching }\end{array}$} \\
\hline $\begin{array}{l}\text { Sample: } \\
\mathrm{Na}_{2} \mathrm{CO}_{3}\end{array}$ & 1:1 & {$[\mathrm{KCN}]$} & $5 \%(w / v)$ \\
\hline $\begin{array}{l}\text { Sample: } \\
\mathrm{NaHCO}_{3}\end{array}$ & 1:1 & {$\left[\mathrm{H}_{2} \mathrm{O}_{2}\right]$} & $\begin{array}{c}10 \mathrm{ml} \text { from } \\
30 \% \mathrm{H}_{2} \mathrm{O}_{2}\end{array}$ \\
\hline $\mathrm{Na}_{2} \mathrm{~S}_{2} \mathrm{O}_{3}(\mathrm{~g})$ & 0.5 & {$\left[\mathrm{Na}_{2} \mathrm{~S}_{2} \mathrm{O}_{3}\right]$} & $5 \%(w / v)$ \\
\hline $\mathrm{pH}$ & 9.5 & $\mathrm{pH}$ & 9.5 \\
\hline Agitation time & $\begin{array}{l}120 \\
\text { minutes }\end{array}$ & Agitation time & $\begin{array}{c}120 \\
\text { minutes }\end{array}$ \\
\hline Temperature & $50^{\circ} \mathrm{C}$ & Temperature & $25^{\circ} \mathrm{C}$ \\
\hline & & $\mathrm{S} / \mathrm{L}$ ratio & $1: 10$ \\
\hline
\end{tabular}

On the light of the obtained results for selective leaching of uranium and gold, a technological flow sheet was elucidated also.

\section{Acknowledgements}

Authors of this work were sincerely appreciated to Professor Ibrahim Katan, emeritus professor in geochemistry, Nuclear Materials Authority, for his cordial help in supporting the studied technological sample in this work.

\section{Notes and references}

[1] Technical Report Series No.359, Uranium Extraction Technology, International Atomic Energy Agency, Vienna (1993).

[2] R. C. Merritt, The Extractive Metallurgy of Uranium, Colorado School of Mines Research Institute, Johnson Publishing Co, Boulder, (1971).

[3] R. W. Bartlett, Solution Mining Leaching and Fluid Recovery of Materials, OPA (Amsterdam) B. V. Gordon and Breach Science Publishers, (1992).

[4] E. T. Romero Guzmán, E. Ordoñez Regil, G. PachecoMalagon, Uranium leaching from phosphate rock, Journal of Radioanalytical and Nuclear Chemistry, v. 201(4), 313- 320 (1995). 
[5] R. Tartèse, P. Boulvais, M. Poujol, E. Gloaguen and M. Cuney, Uranium Mobilization from the Variscan Questembert Syntectonic Granite During Fluid-Rock Interaction at Depth, Economic Geology, v.108, p. 379386 (2013).

[6] S. S. Konyratbekova, A. Baikonurova and A. Akcil, Noncyanide Leaching Processes in Gold Hydrometallurgy and lodine-lodide Applications: A Review, Mineral Processing and Extractive Metallurgy Review: An International Journal v. 36 (3) p. 198-212 (2015).

[7] W. W. Leong Eugene and A. S. Mujumdar, Gold Extraction and Recovery Processes, Minerals, Metals and Materials Technology Centre (M3TC) (2009).

[8] P. J. D. LLOYD, The flotation of gold, uranium, and pyrite from Witwatersrand ores; J. South African Institute of Mining and Metallurgy, pages 41-47 (1981).

[9] Graham J. Sparrow and James T. Woodcock, "Cyanide and Other Lixiviant Leaching Systems for Gold with Some Practical Applications", Mineral Processing and Extractive Metallurgy Review: An International Journal V. 14, (3-4), 1995

[10] K. E. HAQUE, “Gold Leaching from Refractory OresLiterature Survey, Mineral Processing and Extractive Metallurgy Review An International Journal", v.2, (3) (1987)

[11] Bosch D.W., Retreatment of residues and waste rocks, P. 707-743 in Extractive Metallurgy of Gold in South Africa, volume 2, Edited by G.G. Stanly, Johannesburg, South Africa Institute of Mining and Metallurgy (1987).

[12] Wendel G., “Uranium Leaching Modeling at Hartebeestfontein gold mine. Mine Metallurgical Managers Association of South Africa, 2(86): 61-68 (1986).

[13] T. Groenewald and P. A. Laxen; A Combined UraniumGold Leaching Process, Examination of the Feasibility of the Process, Technical Report No. PEL-121, v.5, Atomic Energy Board, Penlindaba, Pretoria, South Africa (1967).

[14] J.G.H. Du Preez, D.C. Morris, C.P.J. Van Vuuren, "The chemistry of uranium. Part XXVI. Alkaline dissolution of gold and/or uranium dioxide powders", Hydrometallurgy v.6 (1-2), 147-158 (1980).

[15] J.G.H. Du Preez, D.C. Morris, C.P.J. Van Vuuren, P. Hendriks, M. Oertell, The chemistry of uranium. Part XXVIII. The development of a combined gold and uranium leach of randfontein ore, Hydrometallurgy, v. 6, (3-4), 203-218 (1981).

[16] I.E.El Assy, M.M. Gabr and E.M.Ibrahim, Base and Rare Metals Bearing Lower Carbonaceous Sandstone in Southwestern Sinai,Egypt, Egyptian Journal of Geology, 2015, v.59, p. 199-208

[17] Hisham K. Fouad, Randa M. Elrakaiby, Mohamed D. Hashim, American Journal of Analytical Chemistry, 2015, 6, 411-421.

[18] Davies W. and Gray W., A rapid specific titrimetric method for the precise determination of uranium using iron (II) sulphate as a reductant, Talanta, 11, 1203-1211 (1964).

[19] Stephens, F.M. and Mc Donald, R.J. (1956); Alkaline leaching of uranium ores, Proceedings of the $1 \mathrm{st}$ International Conference on Peaceful uses of Atomic Energy,Geneva, vol. 8, p.18-25, United Nations, New York.

[20] Rabie, K.A., Abd ElMoneam Y.K., Abd El-Fatah. A. I, Demerdash M., Salem A.R., Adaptation of anion exchange process to decontaminate monazite rare earth group from its uranium content, International Journal of Research in Engineering and Technology, v.3 (6) (2014). 